\title{
ILCEA
}

Revue de l'Institut des langues et cultures

d'Europe, Amérique, Afrique, Asie et Australie

$40 \mid 2020$

English for Specific Purposes (ESP) and the Underlying Dynamics of Power, Empowerment and Disempowerment

\section{ESP Power Issues from the Perspective of an Intentional Approach to Specialised Languages}

Les problématiques de pouvoir en anglais de spécialité à partir d'une approche intentionnelle des langues de spécialité

\section{Michel Van der Yeught}

\section{OpenEdition}

\section{Journals}

Electronic version

URL: http://journals.openedition.org/ilcea/10692

DOI: 10.4000/ilcea.10692

ISSN: 2101-0609

\section{Publisher}

UGA Éditions/Université Grenoble Alpes

\section{Printed version}

ISBN: 978-2-37747-204-8

ISSN: 1639-6073

\section{Electronic reference}

Michel Van der Yeught, «ESP Power Issues from the Perspective of an Intentional Approach to Specialised Languages », ILCEA [Online], 40 | 2020, Online since 04 June 2020, connection on 06 September 2020. URL : http://journals.openedition.org/ilcea/10692 ; DOI : https://doi.org/10.4000/ ilcea.10692

This text was automatically generated on 6 September 2020

(C) ILCEA 


\title{
ESP Power Issues from the Perspective of an Intentional Approach to Specialised Languages
}

Les problématiques de pouvoir en anglais de spécialité à partir d'une approche intentionnelle des langues de spécialité

\author{
Michel Van der Yeught
}

\section{Introduction}

Because words apparently have less immediate power than brute physical force to change the course of events in the material world and yet exercise a more durable influence on the minds and the actions of men, the relations between language and power have fascinated thinkers for centuries, even millennia. One early precursor of investigations into these relations was Gorgias, a sophist in ancient Greece to whom Plato gives centre stage in the Gorgias, one of the philosopher's most famous dialogues. In his Encomium of Helen, Gorgias underlines the influence of language on men-and women, Helen of Troy in this case-with remarkable economy of means: "Speech is a powerful lord, which by means of the finest and most invisible body effects the divinest works [...]." (Patrick, 2012: 11)

In the field of English for Specific Purposes (ESP), there has been some recent interest in the subject: in The Handbook of English for Specific Purposes, Sue Starfield explains how many ESP authors have been influenced by the "critical turn" in language studies that took place in the 1970s and '80s. Instead of merely describing language and discourse mechanisms assumed to be politically neutral and in the natural order of social things, critical theorists brought to light the generally hidden ways by which language and discourse ${ }^{1}$ can influence minds, manipulate opinion and create and maintain unequal relations of power (Fairclough, 1989: 5, 13-14, 109-39; Paltridge \& Starfield, 2013: 4614). Critical approaches study the part played by language in ideologies, politics, racial and sexual issues, the media, cultural and linguistic imperialism, the consumer society, 
advertising, capitalism... (Fairclough, 1989; Simpson, Mayr \& Statham, 2019). For their part, ESP authors generally tend to focus on power issues in the classroom, needs analysis, genre theory and insider/outsider asymmetries (Orts, Breeze \& Gotti, 2017).

While we consider critical approaches in ESP are justified and necessary, this paper does not follow the mainstream critical path. It intends to analyse the relationships between language and power in a descriptive way, and we wish to explain why. ESP authors may have been influenced by the "critical turn" in language studies a few decades ago, but the fact that they study "specialised varieties of English" (SVEs) does not appear to have been specifically factored into their critical approaches. We believe that, among the many research undertakings involving ESP, one of the most important is to account for the process of language specialisation that generates SVEs. As will be suggested in the coming pages, language-power mechanisms are built into the very process of specialisation and, to our knowledge, these mechanisms have not yet been adequately described. It is the purpose of this paper to analyse the power of language in the specialisation processes that generate SLs, and also create specialists, specialised communities and specialised domains. Because of the specialised character of the SVEs under study, not only is such a descriptive stage necessary in ESP, but it should precede critical stages since describing objects of study influences the critical outlook we may have on them (see Searle, 2010: 201).

One appropriate starting point to launch this descriptive project could be to follow the lead of the views expressed in Language and Power by Paul Simpson, Andrea Mayr and Simon Statham, published in 2009 (and reedited in 2019). Though the authors deal with general English-there is no mention at all of ESP-their work helps understand the shift from general English to ESP. In chapter A2 on "The discourse of institutions and organizations", the authors focus on the relationship between language and power in institutional contexts because they see institutions as "inextricably linked to power":

Institutions have considerable control over the organizing of our routine experiences of the world and the way we classify that world. They therefore have the power to foster particular kinds of identities to suit their own purposes because they are primary sites for 'reality construction' [...]. (Simpson, Mayr \& Statham, 2019: 7)

5 In this context, we would like to highlight the point regarding the idea that institutions play a crucial role in the construction of social reality. The authors then go on to develop the idea further as follows:

Linguistic and discourse analytical approaches to institutional research generally regard linguistic exchange as an important aspect of interaction (Fairclough \& Wodak, 1997) where language is understood as constitutive of organizations and institutions. From this perspective, language is the principal means by which institutions create their own social reality. [...] Organizations exist only in so far as their members create them through discourse. This is not a claim that organisations are 'nothing but discourse', but rather that discourse is the principal means by which organizational members create a coherent social reality that frames their sense of who they are. (Mumby \& Clair, 1997: 181, cited in ibid.: 7)

6 Although the authors clearly uphold the fact that institutions create social reality, they fail to provide any explanation as to how such a feat is achieved in practice, leaving readers to wonder how the mechanism of institutional "reality construction" actually works. Another puzzling observation is the fact that a highly prominent author who has specifically addressed the issue of how institutional reality construction operates is never mentioned: in two seminal titles, The Construction of Social Reality (1995) and 
Making the Social World (2010), John Searle, an American philosopher specialising in language and social theory, offers an explanation on how our social world is created and maintained by language thanks to institutional constitutive rules-and though one may not agree with his proposals, they are, nevertheless, worth mentioning if only to be criticised.

7 The fact of including the creation of social reality into the debate is crucial since, as we will try to show, specialisation is one such created social reality. The language and power mechanisms that make such creation possible need to be studied to clarify the relations between language and power in the ESP context. However, in spite of the validity of Simpson, Mayr and Statham's ideas, we must move beyond mere declarations and attempt to show how social facts can emerge from institutional language mechanisms. Searle's theoretical proposals matter here because they show that the construction of social reality involves innumerable and highly sophisticated collective mechanisms in which language and power are closely interwoven. These proposals have contributed to a better understanding of the specialisation processes that generate specialised languages and constitute the foundations of a research project known as the "Intentional Approach" (IA) to SLs based on the theory of intentionality developed by Searle (1983, 2004; Van der Yeught, 2016, 2018, 2019a, 2019b, 2020).

8 The purpose of this paper is to study the relations between language and power in SVEs as envisaged by IA. The first section offers a synthetic presentation of IA that takes the reader from intentionality to specialisedness, social reality, institutions, and to the power of language in social creation. The second section concerns the specific types of powers-"deontic powers"-assigned in keeping with the institutional statuses and functions of social agents, examined firstly as attached to specialist status and then to the use of SLs by specialists. In the third section, we examine how deontic powers can enrich our view of critical approaches to languages and discuss one of Fairclough's diagnoses in two discourse exchanges between protagonists. The discussion then moves on to the case of power-language relationships in the "plain language movement". In section 4, after revisiting the real power of language, we explain that language in itself is essentially powerless. To conclude, a few pedagogical opportunities offered by the language-power theme in ESP are examined, with a special focus on the importance of making learners aware of the deontic powers of their specialisms.

\section{Power and language mechanisms in the Intentional Approach to specialised languages}

\subsection{The origins of the Intentional Approach}

9 In our view, one of the main problems in ESP research is that SLs are rarely, if ever, regarded by scholars as objects of study in their own right, leading to an absence of theories explaining what they are. Two recent definitions of ESP describe it as "the teaching and learning of English as a second or foreign language where the goal of the learners is to use English in a particular domain" (Paltridge \& Starfield, 2013: 2), and as

[...] an approach to language teaching that targets the current and/or future academic or occupational needs of learners, focuses on the necessary language, genres and skills to address these needs and assists learners in meeting these needs 
through the use of general and/or discipline-specific materials and methods.

(Anthony, 2018: 1)

Neither of these two major publications has a chapter devoted to theory as evidenced by the fact there is no "theory" entry in their indexes.

10 The Intentional Approach endeavours to fill that scientific gap by postulating that such language phenomena-SLs like financial English, medical German or legal Frenchexist, and that they can be legitimate objects of study in their own right. Further, it observes that SLs emerge as derivations of professional or disciplinary specialisatione.g. medical English emerged as a result of medical specialisation and not vice versaand it logically concludes that a theory of SLs requires a preceding theory of specialisation to make sense. And yet, while innumerable forms of human specialisation have been extensively studied-in economics, social studies, industrial and technological sciences...--what specialisation is in itself, per se, has rarely attracted the interest of researchers (Van der Yeught, 2016: 42; 2019b: 54-6).

\subsection{From intentionality to specialisedness}

11 Our suggestion is that specialisation, at its core, is a mental phenomenon that belongs to a large group of "intentional mental states" as John Searle describes them. For Searle, intentionality is "that capacity of the mind by which mental states refer to, or are about, or are of objects and states of affairs in the world other than themselves" (2004: 19, 112; see also 1983:1). These intentional states are accompanied by sets of beliefs and desires concerning the object. These beliefs and desires need to be satisfied and constitute, as such, the purpose of intentionalities (Searle, 2004: 118-9). In this explanatory context, we posit that particular intentional states are not fleeting mental dispositions, as most are in our daily lives, but may be considered "specialised" when the mind directs itself towards one specific object of the world in a selected, concentrated and durable way (Van der Yeught 2016: 46-8; 2019b: 63). Consequently, "specialisedness", the fact of being specialised, is the main characteristic of all phenomena that derive from specialised intentional states.

\subsection{From collective intentionality to the creation of social reality}

12 Intentional states are individual to begin with, but Searle shows that they can become collective when shared by a number of persons, as when people play in an orchestra or in a football team, take part in trade unions or set up political campaigns. "Collective intentionality" wields considerable social power in that it has the capacity to create social reality. Such social realties are created through collectively accepted "constitutive rules" that allocate functional power $\mathrm{Y}$ to objects $\mathrm{X}$ in contexts $\mathrm{C}$, following an implicit or explicit verbal declaration that "X counts as $Y$ in C". Searle's own preferred example concerns the creation of the social reality of money through the rule " $\mathrm{X}$ (this specific piece of paper) counts as $\mathrm{Y}$ (a \$20 bill) in C (the United States of America)" (1995: 37-51; 2010:10). Such created social realities are said to be "instituted" and are called "institutions" because they result from declarations that are accepted by collective intentionalities. Although Simpson, Mayr and Statham claim that "the concept of institution itself is curiously hard to define" (2019: 9), in the context of Searle's social ontology, the concept is fairly simple to grasp: institutions refer to any social realities that result from collectively accepted constitutive rules and can, in turn, 
likewise create new institutions. Searle provides a substantial list of the extremely diverse forms these institutions may take. They may be organisations, i.e. social groups composed of members and regulated by statutes, rules or bye laws (corporations, trade unions, churches, sports clubs, political parties, schools...), but they may also be memberless social practices such as money, private property, the U.S. presidency, university tenures, birthday parties, etc. (Searle, 2010: 91-2).

\subsection{Specialised communities, domains and languages as institutions}

By the same power of the " $X$ counts as $Y$ in C" rule, specialised collective intentionalities can also create specialised social realities to serve their purposes. Specialised communities organise themselves into specialised organisations (scientific institutes, professional bodies, research laboratories, learned societies...) and create social objects to meet their needs (procedures, symposia, projects and programmes, professional symbols and logos, uniforms and medals, professional wear and attire...). One example we find particularly illustrative in this context is the institution of the U.S. GAAP (Generally Accepted Accounting Principles) because its very name illustrates the validity of the collectively accepted " $\mathrm{X}$ counts as $\mathrm{Y}$ " rule. Although specialised domains such as physics, banking, medicine, law and accounting are not institutions because they do not derive from collectively accepted constitutive rules, they nevertheless contain an infinite number of related institutions that do.

This analysis naturally applies to the specialisation of languages. Specialised communities also use the " $\mathrm{X}$ counts as $\mathrm{Y}$ in $\mathrm{C}$ " rule to create new words, expressions, phrases, collocations, or to give new meaning to existing words. One example of the latter could be: "bears (X) count as pessimistic investors (Y) in English-speaking stock market contexts (C)", while bulls are optimistic punters. By the same token, specialised genres emerge to serve specialised intentionalities. SLs are institutions that are created by the same language-power mechanisms as all other creations of social reality (Van der Yeught, 2019: chap. 2).

\subsection{The power of language in the process of social creation}

The Intentional Approach adopts the view that language generates enormous social creative power through very simple verbal declarations that are constitutive of the social facts they generate (Searle, 1995: 37). In this sense, Gorgias was right when he said language "effects the divinest works [...] by means of the finest and most invisible body"-which Searle seems to echo when he writes that "there is an element of magic, a conjuring trick, a sleight of hand" in the creation of institutional facts through language (ibid.: 45). He also adds that we live in a "sea of institutional reality" which is constituted by language, but remain largely unaware of the part played by language in the process (2010:90). Owing to the way it is created, institutional reality has specific ontological characteristics: it is ontologically subjective, but epistemologically objective. In other words, its existence depends on the intentional mental states of subjects (hence, its ontology is subjective); yet, once created, institutions can be studied as objects of knowledge in their own right (hence, they are epistemologically objective) (Searle, 1995: 7-9, 12-13, 190-4; 2010: 17-18). 

way. It contains, inter alia, specialised languages that result from specialised intentionalities and their related constitutive rules, and which can be studied, taught and learnt in ESP. In this respect, IA is at odds with Hutchinson and Waters' remark that 'ESP is not a matter of teaching 'specialised varieties' of English. The fact that language is used for a specific purpose does not imply that it is a special form of the language different in kind from other forms" (1987: 18). The approach presented in this paper shows that these SVEs actually do exist as rule-created institutional realities.

\section{Institutions and deontic powers in general and in specialised contexts}

17 With regard to the "X counts as $Y$ in C" rule, the $Y$ "functions" assigned to $X$ objects by constitutive rules include specific forms of power that Searle calls "deontic powers" which we now analyse in the framework of specialised contexts.

\subsection{The characteristics of deontic powers}

Institutions are invaluable in human societies as they are enabling structures. They provide human agents with powers that are far greater and more diversified than the mere physical or material powers they would otherwise wield as persons deprived of institutional functions (Searle, 2010: 105). These "deontic powers" serve the purposes of their underlying intentionalities by regulating relations between people. They assign balanced sets of positive and negative powers that enable agents to do certain things and prevent them from doing others. Positive powers include rights, responsibilities, privileges, entitlements, authorisations, qualifications...; negative powers include obligations, interdictions, duties, penalties, etc. (Searle, 1995: 100). In many cases, these deontic powers are codified in the form of charters of ethics and codes of deontologythe Hippocratic Oath is arguably the first codification of the deontic powers of ancient Greek healers. By the same token, constitutive rules may terminate or nullify statuses with the effect of disempowering agents: presidents, directors and status holders of all types lose their deontic powers when they step down.

In the universe of specialisedness, deontic powers are also widespread in specialised professional and disciplinary communities. The "X counts as $Y$ " rule often takes the form of university degrees, professional certifications and charters, access to job positions or titles that assign statuses and functions together with their related deontic powers to academics, accountants, surgeons, scientists, lawyers... (Searle, 1995: 87). These powers serve the specialised intentionalities of their respective domains by imposing sets of rights and obligations on status holders. They mostly apply to agents' activities (curing patients, managing bank accounts, making legal rulings, trading stocks...), but they may also concern SL use and, as such, it is of interest for ESP actors to examine which deontic powers specifically apply to SL use by specialists.

\subsection{Deontic powers in the use of specialised languages}

Although most specialists are not linguists, SL use is a key capacity in their mission to serve their intentionalities. Accessing specialist status provides them with linguistic 
deontic powers that can be positive or negative. Some of the positive deontic powers they enjoy include:

- the right to use the community's SL as a legitimate insider;

- the possibility of enjoying persuasive authority among peers through SL mastery;

- access to the community's communicative universe (journals, symposia, forums...) as both readers and authors for project and career furtherance;

- the prerogative of expressing their views in keynote lectures, speeches, papers, prefaces, forewords, introductions, media interviews...

21 The foremost and overarching deontic power in SL use, however, is the specialists' right to take part in the collective acceptance process by which the community creates and shapes the SL in question through adapted "X counts as Y" rules. They will typically contribute to committees that decide on SL new words, new meanings, new genres or on their evolution. Recent debates on the concept of anthropocene $e^{2}$ among geologists illustrate the deontic power of these specialists with regard to the evolution of their SL.

Negative linguistic deontic powers include various types of obligations. SL use has to be accurate since malpractice may result from wrong language use in many domains (e.g. law, medicine, air and marine navigation...). It also requires situational relevance because specialists must carefully adapt their discourse to facts, cases, issues, analyses, rulings... Another obligation is keeping up-to-date since preserving their linguistic authority depends on being abreast of SL evolutions. However, the foremost obligation towards the community's collective acceptance of its SL is that, through language creation and evolution, specialists must serve their domain's intentionality, not their own personal interests. One telling example of such conflict dates back to the 1980s and concerns Linus Pauling, an American chemist and twice Nobel prize laureate, who refused to include quasicrystals in the definition of crystal in spite of the fact that Dan Shechtman, an Israeli scientist, had provided scientific evidence of their existence. Pauling had, in fact, acted out of pure personal interest because Shechtman's findings clashed with his own. In 1992 the International Union of Crystallography, braving Pauling's proscription, modified the definition of this key concept and Shechtman was awarded the Nobel Prize for chemistry in $2011 .^{3}$

\subsection{ESP practitioners' deontic powers with regard to SL use}

An ancillary question in this respect concerns whether ESP practitioners as linguists who are not domain specialists, but who presumably master SLs, have specific deontic powers. Our answer would be that they do, but that these deontic powers derive from their status as teachers-thereby serving a different intentionality-and that they markedly differ from those of the specialists. Even though they are not domain insiders and, as such, not entitled to access the community's communicative universe or express their views regarding domain-specific matters, as ESP actors, teachers nevertheless face obligations of accuracy, correctness and up-to-dateness in SL use and instruction. As we see it, the positive deontic powers they can lay claim to-authority in SL-are "encyclopaedic" in nature, a concept we borrow from Umberto Eco (1986: $68-86){ }^{4}$ 


\section{Applying critical approaches to deontic powers}

\subsection{Disentangling deontic powers from social conditions}

In most situations, there is not much to be critical about as regards deontic powers; Searle insists human societies would not work at all without status functions and the distribution of power they imply as these provide the foundations of a major part of our civilised activities (2010: 201-2). In this perspective, we beg to differ slightly from some of critical approaches to power-language relations.

For example, in Fairclough's classic Language and Power, the author analyses "unequal" power relationships expressed through linguistic intercourse between protagonists. His first two examples feature a police officer interviewing a witness (1989: 18-19) and a hospital doctor tutoring a medical student during a visit to a neonatal unit (ibid.: 44-5). Fairclough underlines how the policeman and the doctor keep firm control of the verbal exchange (by interrupting, asking questions and correcting their interlocutor). He observes that the policeman expresses no acknowledgment for the information provided by the witness. He even suggests that the latter would have expected none anyway, while some form of gratitude would have come more naturally in the context of "a friendly conversation". He notes that the doctor's language with his student is often "arrogant", "abrupt" and "curt". He concludes that these examples illustrate how "powerful participants" control and constrain "non-powerful participants" through discourse (ibid.: 46), and that these language properties are not "arbitrary", but are determined by "social conditions" (ibid.: 19).

of course, Fairclough may have a point; on the other hand, he may also have bypassed a crucial characteristic of these verbal exchanges. Both are staged in workplace settings and feature professionals who are assigned institutional functions and their related deontic powers. Admittedly, these actors may misuse or abuse their powers, but the resulting unbalanced relationships expressed in their speech may stem more from mismanaged deontic powers than from their "social conditions" as powerful (or nonpowerful) participants. This would equate deontic powers with social conditions, which, we think, begs demonstration, at least. Indeed, simply imagine-as in the pitch of some Hollywood comedy films-that the professional tables turn. The doctor happens to take amateur sailing lessons with a sailing instructor who is none other than his medical student. In blustery gales and choppy waters, captains tend to be pretty directive in their navigation orders and the doctor-apprentice helmsman would most certainly be sharply told off by his former student-turned-skipper if he messed up at the wheel.

Similarly, fancy the police officer suffers from diabetes and gets a stern dressing-down from his GP-the witness interviewed, as may be guessed-for not sticking to the stringent treatment she has prescribed. Who would be "powerful" and "non-powerful" in these new situations? Inequalities would be totally reversed and it is language that would express the inverted hierarchies. Presumably, these protagonists' "social conditions" have not been turned upside down overnight; however, the new professional circumstances have thoroughly reshuffled their respective deontic powers and overturned power relations. That is why the witness interviewed was not expecting acknowledgment for the information she provided: she knew full well that police 
officers' deontic powers contain no obligation to express gratitude to informants (even if some of them do).

Fairclough's further remark that acknowledgments are expected in friendly conversations fails to realise that professional deontic powers rarely involve friends, and that this amounts to comparing apples and pears. The point is not to deny that social conditions may determine discourse and vice versa, but simply that, in the examples presented by Fairclough, the "social" critical approach seems misguided since professional deontic powers are not factored in. Language users may in turn be one's doctor, sports coach, plumber, banker, yoga instructor, accountant, lawyer, air hostess, tax inspector..., and discourse has to be adapted to evolving deontic situations.

Simpson, Mayr and Statham use an "adapted" version of Fairclough's "doctor/medical student" situation to show how "a more powerful participant interrupt[s] a subordinate person" (2019: 12-13). Their diagnosis broadly follows Fairclough's, but is more analytically nuanced and appears to be surprisingly reminiscent of Searle's theoretical apparatus: "[...] it is the institutionally determined social roles that determine the discoursal rights and obligations of the speakers." (Ibid.: 13) We broadly agree with this conclusion and would simply add that: (1) "institutional determination" is a vague descriptive notion which is more convincingly theorised by Searle's constitutive rules; (2) "social roles" are rather "professional roles", and changing professional situations regularly reshuffle participants' power and subordination; (3) the notions of "rights and obligations" are very convincingly theorised by Searle's deontic powers.

\subsection{Critical approaches to over-specialised languages: the case of plain language movements}

The so-called plain language movement that campaigns against the obscurity of some SLs is another type of critical approach worth examining in our specialised languagepower study. ${ }^{5}$ Plain language activists target what they deem overly complex SLs, especially when these involve public users, which, for instance, is the case for the English of law ("legalese"), technology ("techno babble") and finance ("stock market jargon"). They claim that linguistic obfuscation is produced by specialists on purpose to generate unequal power relations between insiders and outsiders and serve the formers' interests. Public and private initiatives multiply to encourage or force specialised communities to use plain English in, among others, legal, medical and financial discourse. These critical postures aptly point to blatant abuses in linguistic deontic powers. In the beliefs and desires they strive to satisfy, many specialised intentionalities aim to serve the public; artificial over-complexity in language operates as a disservice to outsiders and frustrates this mission. We may, hence, conclude that these plain language critical approaches are fully justified so as to restore a level playing field between SL insiders and outsiders.

31 Yet, the question subsists as to what extent SLs should be made plain. What level of SL simplification or "despecialisation" would seem acceptable to all parties? Can SLs be made as plain as general language? Opinions vary on the subject, but IA paves the way for some suitable answers. As seen above, the example of geologists and crystallographers illustrates the fact that one major linguistic deontic power held by specialists is their right to contribute to the collective acceptance that specialises 
language. It is up to geologists, and none other, to trigger an " $\mathrm{X}$ counts as $\mathrm{Y}$ in C" rule that will make anthropocene an officially recognised concept in their community. If plain language activists intervene in the process, they act without the proper linguistic deontic powers and curtail the specialists' legitimate authority to make constitutive rules in language matters. If SLs become excessively "despecialised", specialised communities may lose the capacity to communicate as they see fit and eventually face extinction.

This denouement is not in the public interest and specialised deontic powers cannot be simply brushed aside. Despecialisation programmes must, at least partly, stem from the specialists' own awareness that their SL needs to be simplified (which is often the case), and a finely tuned balance between their deontic powers and public interest has to be struck to find suitable forms of collective acceptance that preserve the specialists' right to use constitutive rules.

\section{Is language a powerful master? Assessing the actual power of language}

This paper opened with Gorgias' proposition that "speech is a powerful lord" and most books on the "language-and-power" theme emphasise the importance and power of language in shaping human affairs and hierarchies (e.g. Fairclough, 1989: 2-4). Yet, in the light of IA, some of these postures may be revisited to examine the real power wielded by language.

We begin with the fact that Searle's theory of IA posits that intentionality precedes language:

Language is derived from Intentionality and not conversely. The direction of pedagogy is to explain Intentionality in terms of language; the direction of logical analysis is to explain language in terms of Intentionality. (Searle, 1983: 5)

The intentionality of language has to be explained in terms of the intentionality of the mind and not conversely. [...] The meaning of language is derived intentionality and it has to be derived from the original intentionality of the mind. (Searle, 2004: 113)

The resulting fact that language serves the beliefs and desires contained in original intentional states implies that intentionalities are at the origin of power and that language, per se, is powerless. As such, it becomes obvious that it is the intensity of intentional desires and beliefs that generate power. Language, however artful and elaborate, can yield no power if intentional beliefs and desires are lacking.

The example of crystallographers clearly illustrates the point. Linus Pauling's beliefs about quasicrystals were found to be inadequate when serving the purposes of the specialised intentionality of crystallography. His desire to prevail against Shechtman was vigorously expressed through repeated attacks in research symposia and papers. However, colleagues observed that these attacks appeared increasingly depleted of scientific content and were reduced to mere verbal animosity. The influence of Pauling as a public authority and his linguistic virulence proved to be helpless when opposed to a proposition which was serving crystallography better than his own. The bottom line was that language duly followed intentionality; the key concept in crystallography was changed because Shechtman's intentionality proved more powerful than Pauling's. 
37 To conclude on this point, it would appear that Gorgias' proposition needs to be qualified: language is a powerless master, albeit a powerful servant of intentionalities. As the common phrase "empty rhetoric" suggests, language is void of power when it is void of intentionality. ${ }^{6}$

\section{The intentional approach to power-language issues in ESP teaching contexts}

Learners generally appreciate hearing about the benefits to be gained from studying their particular subject-domain. ESP students will certainly be keen to explore the deontic powers of their specialisms, providing them with a number of motivational incentives, and teachers with valuable pedagogical leverage. Students will discover the rights, permissions and entitlements related to their future professional status, but also that the advantages they enjoy balance with duties, obligations and prohibitions. Their linguistic deontic powers will show them how they can become insiders in specialised communities, but also that the requirements of correctness, rigour, accuracy and updatedness expected from them by teachers are symmetrically justified. They will become aware of the need to take heed of power-language issues in their use of SLs with outsiders, especially in specialisms where plain language initiatives urge specialists to respect the public's right to understand what specialised discourse means with regard to their matters of concern.

In the specific case of L2 learners, exploring the deontic world of their English-speaking colleagues will enrich the students' perception of the cultural dimension of specialised communities worldwide. Interesting contrastive pedagogical projects may compare how deontic powers are perceived in the learners' national contexts and abroad. References abound in this field of ESP enquiry and education, both online and in print. Authentic documents include numerous codes of deontology and ethical guidelines, ${ }^{7}$ plain English manuals and recommendations (e.g. Securities and Exchange Commission, 1998; Garner, 2001) which can be used to build case studies, task-based modules, questionnaires, research projects, etc., in order to teach both content and deontic lexis in SLs.

40 For their part, practising and would-be ESP teachers may develop their "encyclopaedic knowledge" in the SLs they teach by exploring the diachronic dimensions of powerlanguage issues, which evolve through time. ${ }^{8}$ While certain communities have been aware of them for a long time and have published codified versions of their commitments, other groups have discovered them relatively recently and have yet to clarify their position on the subject. Historical studies and teaching offer fascinating insights into power-language stakes in specialised communities and SLs.

\section{Conclusion}

41 This paper explores the relations between power and language from the perspective of the Intentional Approach to SLs. A recently updated book on the subject, Language and Power published by Simpson, Mayr \& Statham (2019), offers a starting point in its observation that "language is the principal means by which institutions create their own reality" (ibid.: 7). This proposition is given practical rationality through John 
Searle's theory of collective intentionality in which language creates social and institutional objects through " $\mathrm{X}$ counts as $\mathrm{Y}$ in C" constitutive rules. The validity of the theory lies in that it generates the notion of deontic powers that are attached to social agents' statuses and functions. This theoretical apparatus is then applied to the study of specialisedness in the intentional approach to SLs. It proposes that specialisedness derives from "specialised intentional mental states" and that specialised languages are also created by similar constitutive rules. The relations between deontic powers and language is then explored, both in non-specialised and specialised cases, with an additional focus on the "linguistic deontic powers" of specialists. The Intentional Approach to SLs envisages language-power issues in a more professional way than critical ones which tend to be more socially and politically oriented. Unbalanced social hierarchies featuring powerful and non-powerful discourse participants are viewed less dramatically when professional deontic powers are factored into the analysis than when static social classes seem to be durably pitted against one another by discourse. The paper also tackles the issue of power inequality between SL insiders and outsiders. It agrees that plain language initiatives launched to clarify excessively obscure SLs are fully justified. Yet, it also argues that linguistic demagoguery should not pursue excessive linguistic despecialisation since such moves would seriously impair the inherent deontic rights of specialists to create and modify their SLs. A major inference of the intentional approach leads to underline the intrinsic powerlessness of language itself since the power that it conveys stems from the beliefs and desires generated by intentionalities. The paper concludes that these power-language issues lend themselves to fruitful pedagogical developments. Learners also discover the deontic powers attached to their domain's specialism and their related rights and obligations as future specialists. In the process of constructing their professional profiles, they must be made aware of potentially negative insider-outsider power inequalities, and familiar with the requirements of plain language initiatives to reduce these inequalities.

\section{BIBLIOGRAPHY}

ANTHONY Laurence (2018), Introducing English for Specific Purposes, Oxford: Routledge.

Eco Umberto (1986), Semiotics and the Philosophy of Language, Bloomington, IN: Indiana University Press/Midland Book.

FAIRCLOUGH Norman (1989), Language and Power, New York: Longman Inc.

GARNER Bryan A. (2001), Instructor's Manual: Legal Writing in Plain English, Chicago: University of Chicago Press.

HUtCHINSON Tom \& WATERS Allan (1987), English for Specific Purposes: A Learning-Centred Approach, Cambridge: Cambridge University Press.

LA RocheFouCAULD François de (1977), Maximes [1678], Paris: Garnier-Flammarion. 
ORTS María Ángeles, BREEZE Ruth \& GotTI Maurizio (2017), Power, Persuasion and Manipulation in Specialised Genres, Bern: Peter Lang.

PALTRIDGE Brian \& STARfield Sue (eds) (2013), The Handbook of English for Specific Purposes, Boston, MA: Wiley-Blackwell.

PATRICK Andrew J. (ed.) (2012), Language is a Mighty Lord: A Gorgias Reader, Riposte Publishing.

SEARLE John R. (1983), Intentionality: An Essay in the Philosophy of the Mind, Cambridge: Cambridge University Press.

SEARLE John R. (1995), The Construction of Social Reality, London: Allen Lane/Penguin.

SEARLE John R. (2004), Mind: A Brief Introduction, Oxford: Oxford University Press.

SEARLE John R. (2010), Making the Social World, Oxford: Oxford University Press.

SECURITIES AND EXCHANGE CoMmission/SEC (1998), A Plain English Handbook, Washington D.C.: U.S. Securities and Exchange Commission, <https://www.sec.gov/plainwriting.shtml>.

SIMPSON Paul, MAYR Andrea \& STATHAM Simon (2019), Language and Power [2009], Abingdon, UK: Routledge.

VAN DER YEUGHT Michel (2016), “A Proposal to Establish Epistemological Foundations for the Study of Specialised Languages”, ASp, 69, 41-63.

VAN DER YeUGHT Michel (2018), “Charting the Diachronic Dimension of Specialised Languages: Epistemological Challenges and Pedagogical Relevance”, N. Monnier (ed.), Languages for Specific Purposes in History, Newcastle upon Tyne, UK: Cambridge Scholars Publishing, 1-15.

VAN DER YeUGHT Michel (2019a), "Studying the Diachronic Nature of Specialised Varieties of English through the Intentional Approach to Specialised Languages: Epistemological Stakes and Pedagogical Prospects", J.-P. Charpy, D. Carnet \& L. Gautier (eds), Textes et Contextes, 13(2) [2018, online in 2019], <http://preo.u-bourgogne.fr/textesetcontextes/index.php?id=2329>.

VAN DER YEUGHT Michel (2019b), “Une épistémologie et une théorie des langues de spécialité au service de solutions pour le secteur LANSAD”, C. Chaplier \& A.-M. O'Connell (eds), Épistémologie à usage didactique. Langues de spécialité (secteur LANSAD), Paris: L'Harmattan, 53-95.

VAN DER YEUGHT Michel (forthcoming 2020), “The Intentional Approach to the Theorization of Specialized Languages: An Introduction”, G. Le Cor \& M. Coutherut (eds), Diversité et spécificité des ancrages théoriques en anglais de spécialité, Bern: Peter Lang.

\section{NOTES}

1. In the context of this paper, no significant technical difference is made between language and discourse because it would be of little consequence in the argumentation. For a clear-cut distinction between specialised language and discourse, see Van der Yeught (2019b: 77-8).

2. Anthropocene is a term used to designate the planet's current geological age seen as a period during which human activity exercises the most dominant influence on climate and environment.

3. Numerous newspaper articles have given detailed accounts of Prof. Shechtman's career and discoveries. The most comprehensive was probably published by The Guardian on 6th January 2013: <www.theguardian.com/science/2013/jan/06/dan-shechtman-nobel-prize-chemistryinterview>. 
4. Developing this point is beyond the scope of this paper, but interested readers may find the following references useful to go deeper into the notion of "specialised encyclopaedic knowledge" (Van der Yeught, 2016: 56-7; 2018: 11-13; 2019a: chaps 41-51; 2019b: 78-81).

5. Online and print references to plain language initiatives are extremely numerous. The official website of the U.S. government on plain language features a link to the Plain Language Act 2010: "An act to enhance citizen access to Government information and services by establishing that Government documents issued to the public must be written clearly, and for other purposes". (<www.plainlanguage.gov/guidelines $>$ )

6. Interestingly, a French 17th-century moralist writer, La Rochefoucauld, offers an elegant description of the persuasive powerlessness of language when decoupled from intentionality (passion, in this case). His 8th maxim reads: "Passions are the only advocates which always persuade. They are a natural art, with infallible rules; and the simplest man with passion will be more persuasive than the most eloquent without." (<www.gutenberg.org/files/9105/9105-h/ 9105-h.htm>) ["Les passions sont les seuls orateurs qui persuadent toujours. Elles sont comme un art de la nature dont les règles sont infaillibles; et l'homme le plus simple qui a de la passion persuade mieux que le plus éloquent qui n'en a point."]

7. For example, the Chicago-based Ethics Code Collection is a database that contains over 2,500 modern and historical codes of ethics from 1,500 organisations and some 30 specialisms. Cf. $<$ https://ethics.iit.edu/ecodes/\#main-content>.

8. On the diachronic dimension of SLs and encyclopaedic knowledge, see Van der Yeught (2018 and 2019a).

\section{ABSTRACTS}

The purpose of this paper is to study ESP power issues in the framework of the intentional approach (IA) to specialised languages (SLs). IA has recently emerged in France (Van der Yeught, 2016, 2018, 2019a, 2019b) as an attempt to theorise the study of SLs. It differs from standard ESP postures because it tries to account for "specialisedness"-the mental disposition of a person who specialises-before examining how language serves the purposes of specialisations. The approach is dubbed "intentional" because specialisedness is regarded as one of the forms of "intentionality"-mental states about objects outside the mind-as theorised by American philosopher John Searle (1983, 2004). It is promisingly fruitful to examine power issues in the light of IA because the group extension of intentionality, "collective intentionality", is, in Searle's theory, the main originator of social reality (Searle, 1995, 2010). Since the most common forms of power observable in modern specialised communities are social creations, it makes sense to study them as intentionally-created social realities. Still, until recently, power issues have not attracted notable interest among ESP authors although some researchers have come to bridge the gap (Orts, Breeze \& Gotti, 2017; Paltridge \& Starfield, 2013). This paper first presents a brief summary of the IA project and endeavours to clarify the epistemological standing of power in relation to SLs. The second section is devoted to power allocation in specialised communities, and examines the "deontic powers" (Searle, 2010: 105) that come with specialist status, especially regarding SL use. The third section discusses critical approaches regarding these deontic powers, especially in the context of plain English movements. The fourth focuses on the issue of the actual power of language itself. The final section identifies several attractive opportunities offered by the language-power theme to teach ESP. 
Cet article étudie les problématiques de pouvoir en anglais de spécialité (ASP) dans le cadre de l'approche intentionnelle (AI) des langues de spécialité (LSP). L'AI s'est développée récemment en France (Van der Yeught, 2016, 2018, 2019a, 2019b) afin de théoriser l'étude des LSP. Elle se distingue de l'English for Specific Purposes parce qu'elle s'emploie à rendre compte du « spécialisé " - la disposition mentale d'une personne qui se specialise - avant d'examiner comment la langue sert les finalités de diverses spécialisations. L'approche est dite «intentionnelle » parce que le spécialisé y est conçu comme l'une des formes de "l'intentionnalité » - les états mentaux portant sur des objets extérieurs à l'esprit - telle que John Searle (1983), un philosophe américain, la théorise. Il est prometteur d'envisager les problématiques de pouvoir à la lumière de l'AI parce que « l'intentionnalité collective » constitue pour Searle $(1995,2010)$ l'origine de la réalité sociale. Les types de pouvoir les plus répandus dans les communautés spécialisées modernes relèvent de la création sociale et il est donc pertinent de les étudier comme émanant d'intentionnalités. Néanmoins, malgré quelques publications récentes (Orts, Breeze \& Gotti, 2017 ; Paltridge \& Starfield, 2013), les questions de pouvoir n'ont guère suscité l'intérêt des chercheurs. Cet article présente d'abord un résumé de l'AI et clarifie le statut épistémologique du pouvoir dans ses relations avec les LSP. Une deuxième section est consacrée à l'allocation du pouvoir dans les communautés spécialisées et étudie les "pouvoirs déontiques " (Searle, 2010 : 105) qui sont attachés au statut de spécialiste, en particulier dans l'utilisation des LSP. Une troisième section étudie les approches critiques des pouvoirs déontiques, notamment dans le contexte des mouvements prônant la simplification linguistique. Dans une quatrième section, la question du pouvoir effectif du langage lui-même est posée. La dernière section identifie plusieurs approches pédagogiques prometteuses pour tirer parti de la thématique languepouvoir.

\section{INDEX}

Mots-clés: pouvoir, approche intentionnelle, intentionnalité collective, réalité sociale, pouvoir déontique

Keywords: power, intentional approach, collective intentionality, social reality, deontic power

\section{AUTHOR}

\section{MICHEL VAN DER YEUGHT}

Aix-Marseille Université, LERMA (UR 853), Aix-en-Provence, France.

Michel Van der Yeught is Full Professor at Aix-Marseille University (France). Until recently, President of GERAS, the national French association of ESP practitioners and researchers, he has published widely in the areas of the specialised language, discourse and culture of finance, and the theoretical and epistemological framework of ESP.

michel.vanderyeught@univ-amu.fr 